\section{Monoclonal Antibody Recognizing the Quinoprotein Subunit of Alcohol Dehydrogenase Complex from Gluconobacter Species}

\author{
Emiko Shinagawa, Kazunobu Matsushita, \\ Takeshi Inoue, ${ }^{*}$ Osao AdACHI \\ and Minoru AmeYama
}

Department of Agricultural Chemistry and *Veterinary Medicine, Faculty of Agriculture, Yamaguchi University, Yamaguchi 753, Japan

Received January 30, 1989

Quinoprotein alcohol dehydrogenase (ADH), a key enzyme in vinegar production, is located on the cytoplasmic membrane of acetic acid bacteria and linked to the respiratory chain. We purified ADH from the membranes of two representative acetic acid bacteria, Gluconobacter suboxydans IFO $12528^{1,2}$ and Acetobacter aceti IFO 3284. ${ }^{3)}$ The purified ADHs from G. suboxydans and $A$. aceti have three and four subunits, respectively. It is important to study the role of each subunit and the relationship between $\mathrm{ADH}$ activity and each peptide. In this report, to investigate the participation of the dehydrogenase peptide in ADH activity, we prepared a monoclonal antibody against the dehydrogenase peptide which is one of the three subunits of ADH from $G$. suboxydans, dehydrogenase (mol. wt. $85 \mathrm{kDa})$, cytochrome $c(49 \mathrm{kDa})$ and an unknown peptide $(14.4 \mathrm{kDa})$.

Gluconobacter spp, listed in Table I, were cultivated as described in our previous report. ${ }^{1}$ The protein and $\mathrm{ADH}$ activity were ricusured ${ }^{43}$ and immunoblotting was done ${ }^{5 \text { ) }}$ under the same conditions as reported previously. ADH was purified from the membrane of $G$. suboxydans to homogeneous state as was also described previously. ${ }^{6}$

The preparation of monoclonal antibodies were done under essentially the same conditions as described by Galfre and Milstein. ${ }^{7}$ Male BALB/c mice (6 weeks old) were immunized intraperitoneally with $50 \mu \mathrm{g}$ of the purified $\mathrm{ADH}$ emulsified in complete Freund's adjuvant and after 2 weeks, the mice were further immunized with $100 \mu \mathrm{g}$ of the purified $\mathrm{ADH}$ emulsified in incomplete Freund's adjuvant. After 1 week more, the mice were boosted with $100 \mu \mathrm{g}$ of the antigen and fusion was done after 3 days. NS-1 myeloma cells were cultured in RPMI1640 (Nissui) supplemented with $15 \%$ fetal calf serum (FCS) and antibiotics $(50 \mathrm{IU} / \mathrm{ml}$ of penicillin $\mathrm{G}$ and $50 \mu \mathrm{g} / \mathrm{ml}$ of streptomycin). Spleen cells from the immunized mice were fused at a 5:1 ratio with myeloma cells using $50 \%$ polyethylene glycol 4000 in RPMI-1640. The cells were plated into 96 -well tissue culture plates at a density of $5 \times 10^{5}$ spleen cells per well $(100 \mu \mathrm{l})$ and selected by adding selective medium containing RPMI-1640, $15 \%$ FCS, and HAT $(100 \mu \mathrm{M}$ hypoxanthine, $0.4 \mu \mathrm{M}$ aminopterin, and $16 \mu \mathrm{m}$ thymidine). After 10 days, the culture fluid was assayed for anti-ADH activity by enzyme-linked immunosorbent assay (ELISA) as described later. Hybridomas producing antibodies were cloned by the limiting dilution method. All monoclonal antibodies from several hybridomas obtained were shown to react with the dehydrogenase peptide with immunoblotting. We selected a hybridoma having the highest anti-ADH activity and obtained the monoclonal antibody from the hybridoma supernatant as a $50 \%$ ammonium sulfate precipitate.

ELISA was done as follows. Fifty microliters of the purified $\mathrm{ADH}(10 \mu \mathrm{g} / \mathrm{m})$ of protein) in $0.1 \mathrm{M}$ carbonate buffer, $\mathrm{pH} 9.5$, was dispensed in each well of the microplate (Greiner). After overnight incubation at $4^{\circ} \mathrm{C}$, the solution was aspirated off. After blocking with $0.2 \%$ gelatin for $1 \mathrm{hr}$ at room temperature, wells were washed four times with phosphate buffered saline containing $0.1 \%$ Tween 20 (PBS-Tween) and $50 \mu \mathrm{l}$ of hybridoma supernatant or conventional antibodies were added to each well of the plates, which were incubated for $2 \mathrm{hr}$ at $37^{\circ} \mathrm{C}$. After the wells were washed, $50 \mu \mathrm{l}$ of the peroxidase-labelled goat anti-mouse immunoglobulins (Cappel) were added to each well. After incubation for $2 \mathrm{hr}$ at $37^{\circ} \mathrm{C}$, wells were washed four times with PBS-Tween and then were filled with $100 \mu$ l of substrate solution (McIlvaine buffer, $\mathrm{pH}$ 5.0, containing $2 \mathrm{mM}$ o-phenylenediamine and $0.02 \% \mathrm{H}_{2} \mathrm{O}_{2}$ ). After incubation for $30 \mathrm{~min}$ at room temperature the enzyme reaction was stopped by the addition of $50 \mu \mathrm{l}$ of $4 \mathrm{M} \mathrm{H}_{2} \mathrm{SO}_{4}$. The absorbance of the solution was read at
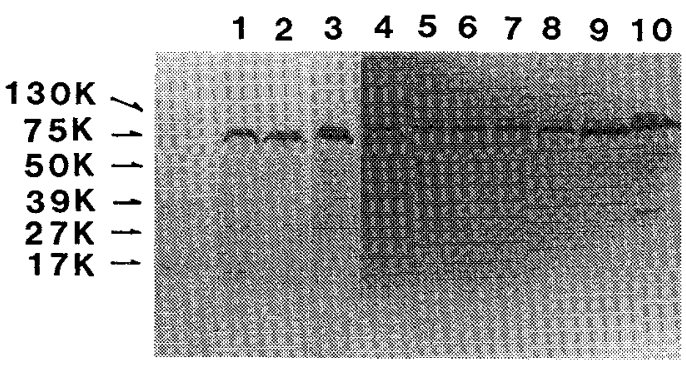

Fig. 1. Immunoblotting of Membranes from Gluconobacter spp. with Monoclonal Antibody against the Dehydrogenase Peptide of Alcohol Dehydrogenase.

Each membrane $(100 \mu \mathrm{g}$ of protein) was electrophoresed by SDS-PAGE and immunoblotted as described in the text. $1, G$. nonoxygluconicus IFO $3275 ; 2, G$. gluconicus IFO $3286 ; 3, G$. cerinus IFO $3265 ; 4, G$. suboxydans var. $\alpha$ IFO $3257 ; 5, G$. suboxydans var. $\alpha$ IFO $3256 ; 6, G$. suboxydans var. $\alpha$ IFO $3255 ; 7, G$. suboxydans var. $\alpha$ IFO $3254 ; 8$, G. suboxydans IFO $3130 ; 9$, G. suboxydans IFO $3172 ; 10, G$. suboxydans IFO 12528. 
Table I. Alcohol Dehydrogenase Activity IN Gluconobacter SPECIES

Enzyme activity was assayed with membrane fraction using phenazine methosulfate-2,6-dichlorophenolindophenol as an electron acceptor, and expressed by specific activity (units/mg).

\begin{tabular}{|c|c|}
\hline Strain & $\begin{array}{l}\text { Enzyme } \\
\text { activity }\end{array}$ \\
\hline G. oxydans IFO 3189 & 0.11 \\
\hline G. oxydans IFO 3287 & 1.55 \\
\hline G. dioxyacetonicus IFO 3272 & 0.86 \\
\hline G. cerinus IFO 3262 & 1.53 \\
\hline G. cerinus IFO 3265 & 0.51 \\
\hline G. cerinus IFO 3268 & 0.92 \\
\hline G. cerinus IFO 3270 & 0.69 \\
\hline G. gluconicus IFO 3285 & 0.34 \\
\hline G. gluconicus IFO 3286 & 0.17 \\
\hline G. albidus IFO 3251 & 0.94 \\
\hline G. albidus IFO 3253 & 1.73 \\
\hline G. suboxydans IFO 3130 & 0.21 \\
\hline G. suboxydans IFO 3172 & 0.34 \\
\hline G. suboxydans IFO 12528 & 3.70 \\
\hline G. suboxydans var. $\alpha$ IFO 3254 & 0.02 \\
\hline G. suboxydans var a IFO 3255 & $\operatorname{tr}^{*}$ \\
\hline G. suboxydans var. a IFO 3256 & 0.01 \\
\hline G. suboxydans var. $\alpha$ IFO 3257 & $\operatorname{tr}{ }^{*}$ \\
\hline G. suboxydans var. IFO 3258 & $\operatorname{tr}^{*}$ \\
\hline G. nonoxygluconicus IFO 3275 & 0.77 \\
\hline G. nonoxygluconicus IFO 3276 & 3.62 \\
\hline G. rubiginosus IFO 3244 & 1.63 \\
\hline
\end{tabular}

* Enzyme activity was less than 0.01 units $/ \mathrm{mg}$.

$450 \mathrm{~nm}$.

Immunocross-reactivity of the membranes of twentytwo Gluconobacter strains was examined by an immunoblotting using the monoclonal antibody against the dehydrogenase peptide and all strains examined here revealed this peptide is present in variable amounts in the membranes as shown in Fig. 1 which is a part of an immunoblotting sheet. The results could not shown the correlation of the amount of the dehydrogenase peptide with ADH activity. Although all strains of $G$. suboxydans var. $\alpha$ scarecely showed $\mathrm{ADH}$ activity as described in Table I, the $85-\mathrm{kDa}$ peptide could be observed in these strains. These strains have been shown to contain little amount of the cytochrome $c$ peptide, which is different from most of Gluconbacter sp. having high concentrations of cytochrome $c$ (unpublished results). Thus, ADH activity seems to be dependent on not only the dehydrogenase peptide but also the cytochrome $c$ peptide.

Acknowledgments We would like to thank Mr. A. Tomikawa and $\mathrm{Mr}$. H. Takahara for their helpful assistance.

\section{References}

1) O. Adachi, K. Tayama, E. Shinagawa, K. Matsushita and M. Ameyama, Agric. Biol. Chem., 42, 2045 (1978).

2) O. Adachi, E. Shinagawa, K. Matsushita and M. Ameyama, Agric. Biol. Chem., 46, 2859 (1982).

3) O. Adachi, E. Miyagawa, E. Shinagawa, K Matsushita and M. Ameyama, Agric. Biol. Chem., 42, 2331 (1978).

4) M. Ameyama, K. Tayama, E. Miyagawa, E Shinagawa, K. Matsushita and O. Adachi, Agric. Biol. Chem., 42, 2063 (1978).

5) K. Matsushita, E. Shinagawa, T. Inoue, O. Adachi and M. Ameyama, FEMS Microbiol. Lett., 37, 141 (1986).

6) M. Ameyama and O. Adachi, Methods Enzymol., 89, 450 (1982).

7) G. Galfre and C. Milstein, Methods Enzymol., 73, 3 (1981) 